\title{
A Review of the Costs and Results of the Various Public Health Activities.
}

\author{
By W. Allen Daley, M.D., B.S., B.A., B.Sc., D.P.H., Medical Officer of
} Health, Blackburn (Member).

HAVE been led to prepare this paper because the time has now come when, as a result of the urgent need for private and public economy, a careful review must take place of the value received for every form of municipal or State expenditure. With regard to expenditure on efforts to preserve the health of the people, it is agreed generally that it would be false economy to restrict expenditure on any sure and certain method of improving the public health. Expenditure on roads or parks, for example, might be postponed and taken up in two or three years without any permanent harm to the community, but in considering the question of postponing expenditure on saving life, we must remember that the dead do not rise, and that for want of their care those dependent on them often become a burden instead of an asset to the community. A grave responsibility, therefore, rests both upon those who advocate the expenditure of large sums of public money on schemes, the value of which is open to question, and upon those who advocate the postponement of schemes the utility of which has been proved. The great need of the moment, therefore, is to decide which public health work is of proved value, which has its value umproven and which, if any, may be regarded as comparatively ineffective. It is one of the difficulties of our work that its triumphs are invisible, and only its failures patent. The story of the averted epidernic is lost in the pages of an annual report, but the raging pestilence is known to all.

The primary objects of a health service are to reduce sickness and postpone death. Statistics with regard to sickness are very scanty, even now, ten years since the passing of the first National Insurance Act, save with regard to the notifiable acute infectious diseases, and these are of little relative value so far as adult workers are concerned. There is no evidence that the amount of sickness amongst insured persons has been appreciably reduced since the Act of 1911 came into operation.

With regard to the acute infectious diseases, though some show evidence of being controlled, the statistics for others form melancholy reading. Plague, cholera, typhus fever and small pox have almost disappeared from the country: typhoid fever has been very much reduced; the deaths from scarlet fever are very small, but the number of cases shows little change; the number of cases of diphtheria shows it tendency to increase; 


\section{Costs and Results of various Public Health Activities.}

measles and whooping cough (now more formidable than any of the infectious diseases yet mentioned) show no sign of lessening their toll of lives.

In connection with the campaign against the acute infectious diseases (to combat which the Public Health Service was formed) four periods may be discerned :-

1. The campaign against filth and insanitation which resulted in the provision of a pure water supply, sewerage, scavenging, building bye-laws, etc., and which caused the disappearance of typhus fever.

2. The period of the compulsory Vaccination Acts, which ultimately caused the disappearance of smallpox, save when imported from abroad.

3. The period when isolation hospitals were erected throughout the country with the expectation that the diseases treated therein, particularly scarlet fever and diphtheria would disappear. Their failure as preventive agents is due to the presence of "carriers" of disease, who spread infection without being ill themselves, and to the fact that in many infections the patient has infected others before his disease has been diagnosed.

4. The fourth stage, which we are now entering, is one where it is recognised that the source and fountain of most infectious diseases is man himself. and that in the education of the individual on the subject of his health lies the best hope of controlling the spread of these diseases; further education on health will lead to a knowledge of how to live so as to prevent disease and of the first signs of serious illness so that a doctor may be consulted early.

With regard to the postponement of death, the second great object of the Public Health Service, the last Life Table issued by the RegistrarGeneral, based on the experience of the years 1911-12, shows that the expectation of life at birth for males has been increased from 40 to 51 years since the issue of the first Life Table, which was based on the experience of the years 1838-54. For females the increase has been from 42 to 55 years. Further, the reduction in the average death-rate of 30 to 40 years ago compared with the average death-rate of the last ten years, shows throughout England and Wales a saving each year of no less than 187,000 lives.

The many factors involved in this reduction give ample scope for disagreement as to which are the principal ones. We are mostly concerned to-day in considering what effect, if any, the Public Health Service has had in this reduction. We may divide public health work into two main classes : in the first lies what may be called "sanitary engineering work," for example, water supply, etc., and the other services, which came into being as a result of the campaign against filth and insanitation. Their effect on the reduction of the death-rate, even if measured solely by the prevention of loss of life from typhus and typhoid fevers, must be consider- 
able. They are essential services, and they must be continued ; the possibility of economy in both scavenging and sewage disposal by the adoption of newer methods is being fully considered by those concerned.

The second class of public health work is that about the relative value of which there is room for controversy. It is the work actually performed in the Medical Officer of Health's department and under his immediate supervision. It includes work directed primarily against infectious diseases, for example, the provision of pathological laboratories, hospitals and ambulance and disinfection services; anti-tuberculosis work (including dispensary, hospital and sanatorium ); maternity and child welfare work; work directed against venereal diseases; the School Medical Service; Food Control; the control of nuisances, workshops, repair of insanitary houses, etc. An attempt was made to ascertain the national expenditure on this and all other health work. It was unsuccessful and I, therefore, asked my colleagues, the Medical Officers of Health of County Boroughs to send me particulars of the expenditure of their departments during 1919-20, the last financial year for which full particulars are available. I am most indebted to them for having so kindly acceded to my request. Figures have been prepared showing the gross cost of the services per head of the population and per $£$ of rateable value. The actual payments by the ratepayers of the towns concerned being, however, somewhat less than those indicated owing to the Government paying 50 per cent. of the cost of antituberculosis, maternity and child welfare and school medical service work, and 75 per cent. of the cost of measures taken against venereal diseases. The figures show variations in the cost of health work from 2s. 3d, to 9s. $4 \mathrm{~d}$. per head of population and from $3 \frac{3}{4}$ d. to 2 s. $6 \mathrm{~d}$. per $£$ of rateable value. An analysis of the expenditure shows that for every $£ 100$ expended on health work :-

$£ 26$ is spent on work against infectious diseases, mostly hospital maintenance.

30 on anti-tuberculosis work.

13 on maternity and child welfare.

5 venereal diseases.

9 School Medical Service.

2 Food Control (though this figure does not include the cost of the Abattoir in cases where this is controlled by a Markets' Committee).

15 administration and work on general sanitation.

An attempt was made to discover whether there is any difference in the vital statistics of places where much and where little is spent on health work, but for many reasons it was felt that no satisfactory result could be obtained 


\section{Costs and Results of various Public Health Activities.}

without a very elaborate analysis of present and past expenditure and statistics.

The principal matter for discussion is whether the present allocation of money spent by Health Departments is the best possible, or whether better results could not be obtained by other methods. In this connection it is necessary to note how popular opinion influences public health expenditure, for example, the distribution of disinfectants is demanded by the public and sometimes acceded to by a Health Committee, but except in a few cases, such as the disinfection of sputum or excreta, their sole result is to replace one unpleasant smell by another. Political expediency influences expenditure: the phrase "first-class hotels" has caused an incalculable amount of discontent in Sanatoria and has led to the erection of expensive structures as Sanatoria, when often lighter and cheaper ones would have done just as well. Again, moral considerations have to be included, for example, the cheapest way to control venereal diseases would be the distribution of packets, but the moral objections are so great that this is not likely to be an agreed policy.

In many schemes great results are produced at the beginning, when there is much scope for improvement, but further advance takes place only with great difficulty: a moderate expenditure produces in ships and trains a certain speed, but for every mile an hour beyond this the extra cost is very much higher. This is probably the case in maternity and child welfare work; a small expenditure on Health Visitors and Schools for Mothers undoubtedly produces splendid results, but when a little more is desired and hospitals are built the expenditure rises by leaps and bounds. On the other hand, in infectious diseases success, by reducing the number of cases, leads to still further success with less instead of greater expenditure.

It is difficult to get away from tradition and to realise that we must judge all our work by the effect it will have on the health of the individual. The following list of relative values may be offered as a basis for discussion: I include only those duties commonly carried out in a Medical Officer of Health's department, and exclude, therefore, such eminently Public Health measures as Registration of Births and Deaths, Vaccination, Hospital Treatment of the Sick Poor, Water Supply, Scavenging, Sewage Disposal etc. :

\section{Relative Values of Public Health Work. Infectious Disease Services.}

\begin{tabular}{lllllccc} 
& & \multicolumn{4}{c}{$\begin{array}{c}\text { Home Supervision } \\
\text { incliding } \\
\text { Supervision } \\
\text { of Contacts. }\end{array}$} & Total. \\
Scarlet Fever & & & & \multicolumn{4}{c}{ Hospital. } \\
Diphtheria & $\ldots$ & $\ldots$ & $\ldots$ & $\ldots$ & $\mathbf{5}$ & 5 & 10 \\
& $\ldots$ & $\ldots$ & $\ldots$ & $\ldots$ & 20 & 10 & 30
\end{tabular}




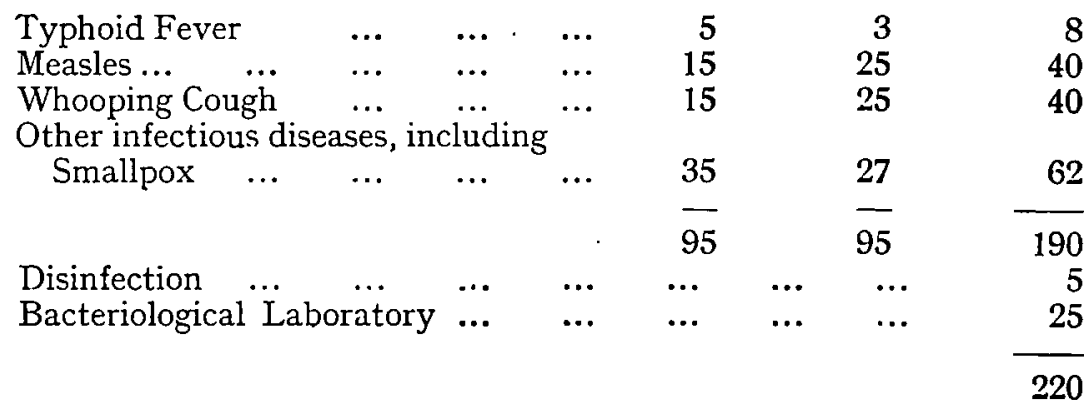

Tuberculosis.

Tuberculosis Dispensary, including home visiting of $\begin{array}{llll}\text { cases and work of Tuberculosis Officer } & \ldots & \ldots & 25\end{array}$

$\begin{array}{lllllll}\text { Pulmonary Hospital } & \ldots & \ldots & \ldots & \ldots & \ldots & 15\end{array}$

$\begin{array}{llllll}\text { Non-Pulmonary Hospital } & \ldots & \ldots & \ldots & \ldots & 15\end{array}$

$\begin{array}{lllllll}\text { Sanatoria-Adults } & \ldots & \ldots & \ldots & \ldots & \ldots & 10\end{array}$

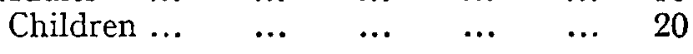

Maternity and Child Welfare.

$\begin{array}{lllllll}\text { Home Visiting } \ldots & \ldots & \ldots & \ldots & \ldots & \ldots & 50\end{array}$

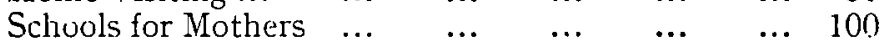

Infants' Hospitals (as at present run) $\quad \ldots \quad$. $\quad \ldots \quad 30$

Maternity Hospitals and Ante-natal work $\ldots \quad \ldots \quad \ldots \quad 50$

$\begin{array}{lllllll}\text { Supervision of Midwives } & \ldots & \ldots & \ldots & \ldots & 20\end{array}$

$\begin{array}{lllllll}\text { Vencreal Discases ... } & \ldots & \ldots & \ldots & \ldots & \ldots & \ldots\end{array}$

School Medical Service.

No value if inspection only; the value given includes

treatment and open-air schools $\quad \ldots \quad \ldots \quad \ldots$

Food Control (excluding Milk).

$\begin{array}{llllllllll}\text { Adulteration } & \ldots & \ldots & \ldots & \ldots & \ldots & \ldots & \ldots & & 1\end{array}$

$\begin{array}{llllll}\text { Wholesomeness and Sanitation } & \ldots & \ldots & \ldots & \ldots & \\ & & & & & 9\end{array}$ Milk.

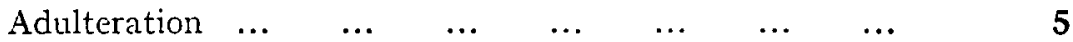

Wholesomeness, including action against dirty and $\begin{array}{llllllll}\text { tuberculous milk } & \ldots & \ldots & \ldots & \ldots & \ldots & \ldots & \\ \end{array}$

$\begin{array}{llllllll}\text { Repair of Unfit Houses } & \ldots & \ldots & \ldots & \ldots & \ldots & & 10\end{array}$

$\begin{array}{lllllll}\text { Removal of Nuisances } & \ldots & \ldots & \ldots & \ldots & \ldots & 10 \\ \end{array}$

Propaganda on Health, including preparation and publication of vital statistics and Annual Report $\quad \ldots \quad \ldots \quad \ldots$

The values given in each case represent, in the opinion of the writer, the results as shown by their effect on the prevention of sickness or postponement of death of the efforts of well-organised Public Health Departments of our 


\section{Costs and Results of various Public Health Activities.}

great towns. It is assumed that all gross conditions of insanitation, for example, privy middens, have been dealt with. New methods and new discoveries may materially alter these values, for example, if a reliable cure for pulmonary tuberculosis were discovered, the relative value of antituberculosis work would have to be very much increased; if a cure for advanced cancer were available, a place would have to be found for it in our scheme; if all the Public Health work of the town were done by the Health Department an entire redistribution would be necessary to provide for vaccination, general hospital treatment, etc., while certain work, for example, administration of Sale of Food and Drugs Acts, Rats and Mice Destruction Acts, issue of certificates under Increase of Rent Act, may have little or no effect on health, and therefore receive a very small value in our table, yet it must be admitted that they can be most effectively administered in a Health Department.

It will be noted how largely these suggested values differ from the values set by the general public upon our work, most of whom regard the removal of nuisances, including ashpit refuse, and the detection of food sophistication, as the chief work of a Medical Officer of Health. If one compares the actual expenditure of Public Health Departments against these suggested values, it will be noted that we are apparently spending too much on work against acute infectious diseases, too much on anti-tuberculosis work, and not enough on maternity and child welfare, on venereal diseases and school medical work. When the very heavy cost of maintaining the scarlet fever wards is considered it does appear desirable to revise our present methods by which hospital treatment is afforded whenever this is desired by the patient's friends. With regard to the expenditure against tuberculosis, our present methods appear to be inadequate, but newer methods will no doubt be evolved.

I must acknowledge my indebtedness to many Medical Officers of Health for the supply of information and to my colleagues Dr. Ewing and Mr. Fowler for helpful work with the figures.

\section{REFERENCES.}

New York State Health News, December, 1920.

Charles V. Chapin, M.D.

The Evaluation of Health Activities.

Sir GEORGE NEWMAN.

The Lady Priestley Memorial Lecture.

The following took part in the discussion on this paper Dr. C. S. Thomson (Hyde); Dr. A. Trimble (Belfast); Dr. S. G. Moore (Huddersfield); Dr. J. Middleton Martin (Gloucestershire). 